\title{
近代日本画家横山大観の上野池之端邸（住宅画室）庭園の特徴に関する考察
}

\section{A Study on Characteristics of Modern Japanese-style Painter Yokoyama Taikan's Residence-atelier Garden at Ueno Ikenohata}

\author{
天野 公太朗* 松本 恵樹** 國井 洋一*** 鈴木 誠*** \\ Kotaro AMANO Yoshiki MATSUMOTO Yoichi KUNII Makoto SUZUKI
}

\begin{abstract}
Yokoyama Taikan Memorial Hall was used as a residence-atelier during 1909-1945 and 1953-1958 by Taikan Yokoyama (1868-1958) who was a representative of modern Japanese-style painter. There is a characteristic garden in the former Taikan Yokoyama residence. In 1909, Taikan built a residence-atelier at Ueno Ikenohata on the banks of Sinobazunoike where was a famous cultural and scenic place of Tokyo. However, unfortunately the residence-atelier had destroyed by an air raid on Tokyo in 1945 and the garden had damaged also. After that, Taikan's residence-atelier was rebuilt and his garden was restored by his strong intention. We had on-site surveying the garden, considering Taikan's career, analyzing relationships between his representational paintings and the garden features, and interviewing to Mr. Jiro Fujii who was involved in the restoration of the garden. In the result, we found that Taikan ordered to plant the trees and shrubs in the garden, just like he painted on his pictures. The garden was landscaped to have more spiritual meaning than natural landscaped garden by his intention. This attitude toward to the garden was different from the gardens created by the other representative of modern Japanese-style painters.
\end{abstract}

Keywords: Taikan YOKOYAMA, residence-atelier garden , Japanese-style painter, modern Japanese garden, Ueno Ikenohata キーワード：横山大観，住宅画室庭園，日本画家，近代日本庭園，上野池之端

\section{1. はじめに}

明治・大正・昭和時代初期にかけては日本画の隆盛期といえる 時代であり，全国で数多くの画家たちが活躍した。それと同時に 画家たちは当時の資産家や地主といったパトロンとなる有産階級 や，文化に精通し教養ある文士や他の芸術家との交流を深めると ともに，経済的に裕福となり，それぞれがアトリエを設けた住宅 を営んだ。京都画壇を代表する画家である竹内栖鳳（1864-1942） は東山山麓の高台寺に本宅を，嵐山をのぞむ嵯峨の地に別宅・霞 中庵を営み，栖鳳の弟子であった橋本関雪（1883-1945） は白沙 村荘を開いた。そして，これらの住宅には庭園も造られ，作庭に あたって画家たちが自ら指揮監督したことが知られている1)。

横山大観記念館（東京都台東区池之端）は，近代を代表する日 本画家，横山大観 (1868-1958) が明治 42 年から昭和 33 年 （1909-1958）の間に住宅画室とした場所である。この旧横山大観 邸には特徴のある庭園が現存する。明治 42 年 (1909), 大観は当 時, 東京の著名な景勝地であった不忍池のほとりである池之端に 住宅画室を営んだ。しかし不幸なことに，この住宅は昭和 20 年 （1945）の東京大空襲により焼失し，その庭園は損傷した。その 後昭和 29 年 (1954), 大観の強い意向により住宅はかつて同様に 再建され庭園も修復された。本研究では，横山大観がこだわりを 持ったこの庭園の特徴を明らかにすることにした。

研究方法としては，庭園の実測調査，横山大観の経歴・絵画作 品と彼の庭園との関係分析，そして庭園の修復に関わった藤井二 郎氏と横山大観の孫であり横山大観記念館館長である横山隆氏 のヒアリング調査を行った。これをふまえ，近代日本画家横山大 観の住宅画室としての庭園の特徵と，池之端に立地した場所の意 味について考察を加えた。

\section{2. 近代日本画家の庭園に関する既往研究}

横山大観本人やその作品に関する研究は存在するが庭園に関す る研究は特に見当たらなかった。ただし，大観の描いた花鳥画や
風景画の分析や研究は, 彼の自然観や興味の対象を知る上で貴重 な資料である。

庭に関連した既往研究として小野 (2000) は京都の著名な日本 画家, 神坂雪佳, 竹内栖鳳, 山本春挙, 橋本関雪の庭園を考察し ており, それぞれの庭園の概要や変遷, デザインや特徴, 画家と の関係や画家の美意識が庭園に与えた影響を具体的・体系的に整 理した。そこから，画家たちが作庭に積極的に関わり，庭師にと って庭園意匠の相談相手という立場で自身の美意識や趣向を庭園 のデザインに表現し，大きく影響を与えたことを指摘している2)。

また，吉田（2009）は近代日本画家・川合玉堂の旧別邸二松庵 庭園について研究し，玉堂の自然観や，画家・作庭者との関係か ら庭園の特徵を分析している。そして，二松庵庭園の位置づけは 京都の画家たちと同様に, 自然風景要素が実物大に写実的に表現 され，園外景観を借景した自然主義風景式庭園の範疇にあると結 論付けている3)。

本研究では既往研究で述べられたように，横山大観の庭園にも 同時代に活躍した日本画家たち同様に，自身の美意識が庭園のデ ザインに表現されていると考えた。その一方で，大観は絵画では 写実的な表現を行なわず，精神性、抽象性を重視する感性をもつ ており，その庭園には，写実的な表現をする自然主義風景式庭園 との違いはないか考察した。

\section{3. 研究方法}

(1) 文献調査

横山大観の経歴やその作品概要，旧横山大観邸庭園のある池之 端の歴史，庭園の作庭経緯を知るために文献調査を行った。また 庭園内には, サクラ, ウメ, イロハカエデなど大観が好み, 画材 として多く描いた4)植物が植えられており, それらを題材とした 大観の花鳥画・風景画の特徴について考察した。

(2) ヒアリング調査

横山大観の人物把握や自然観と庭園との関係を把握し, 庭園の

\section{*東京農業大学大学院農学研究科造園学専攻 **春秋設計工房近代庭園研究室 $\quad *$ 東京農業大学地域環境科学部造園科学科}


修復当時の状況や大観本人の生活ぶりを知るために，関係者への ヒアリング調査を実施した。調査は 2013 年 7 月 23 日に庭園修復 時に岩城造園に所属していた藤井二郎氏, 2013 年 11 月 16 日に大 観の孫で横山大観記念館館長である横山隆氏に対して行った。

\section{(3) 現地調査}

旧横山大観邸庭園の現況を知るために庭園を 3D データ測量を もとにして実測し平面図を作成した。(図一1) また, 庭園内の植 栽を調査し，現況の植生を記載した。

2013 年 12 月 19 日に実測した平面図をもとに藤井二郎氏, 横山 隆氏と共に庭園内を踏査し，ヒアリング調查で得た表一1 の内容 を現地で確認した。

\section{4. 調査結果}

\section{（1）旧横山大観邸の位置する池之端の近代}

旧横山大観邸が営まれた東京都台東区池之端は当時，下谷区茅 町となっており，不忍池の西側の池岸に位置している。元々は明 治時代に日本郵船の専務を勤めた浅田正文 (1854-1912) の邸宅が あり，大正元年（1912）の地籍台帳によれば下谷区茅町二丁目 15 〜18 までの地主は浅田正文であり, 19 は圓城とくという人物のも のであった5)。昭和 10 年（1935）の台帳では浅田と圓城の名義は なく二丁目 18は分割され二丁目 18-2 と 19 は横山秀麿(横山大観) の名義となっているの。それ以前については，明治時代のジャー ナリスト・政治家である福地源一郎の邸宅で, 池之端御殿と呼ば れた茶室を設けた豪邸があり，破産しその豪邸を維持できなくな った福地から浅田が買い取ったと思われるが，それを示寸文献は 現在見当たらない。しか福地の池之端御殿が下谷区茅町 16 に存 在し7), 福地と浅田はともに茶を好み益田孝 (三井財閥の実業家,

茶人）が開いた茶会で交流がある8)ため十分に考えられる。

\section{（2）旧横山大観邸の変遷}

大観は, 明治 39 年 (1906) 日本美術院が茨城県五浦に移転した 際はその傍に住宅を設けた。しかし明治 41 年 (1908) に焼失した ことを契機に，池之端に仮住まいを求め，現在と同じ場所下谷区 池之端茅町二丁目十九番地に住居を新築したのは翌明治 42 年 (1909）のことである ${ }^{9)}$ 。池之端はかつて家族と暮らしていた下 谷区谷中初音町の日本美術院舎宅に近く，対岸には日本美術学校 があるなど大観にとっては非常になじみの深い場所であった。

大正 8 年 (1919) には隣家を買い取り，土地を広げて新築した 邸宅は, 木造瓦草の数寄屋建築で庭園には竹林と池を設けた ${ }^{10)}$ が, 大正 12 年～15 年（1923～1926）にか外て関東大震災に伴う自宅 の修復に伴い，庭園を拡張した。その際，大観が五浦に住んでい

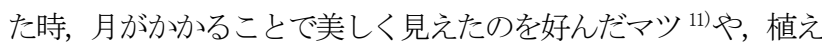
た後も自分と同じで年寄りだと喜んで観察していたウメなどを 植えて、大観の好みを取り入れるように手が加えられている。

\section{表-1 藤井二郎氏へのヒアリング調査からえられた横山大観の庭園に関する指示}

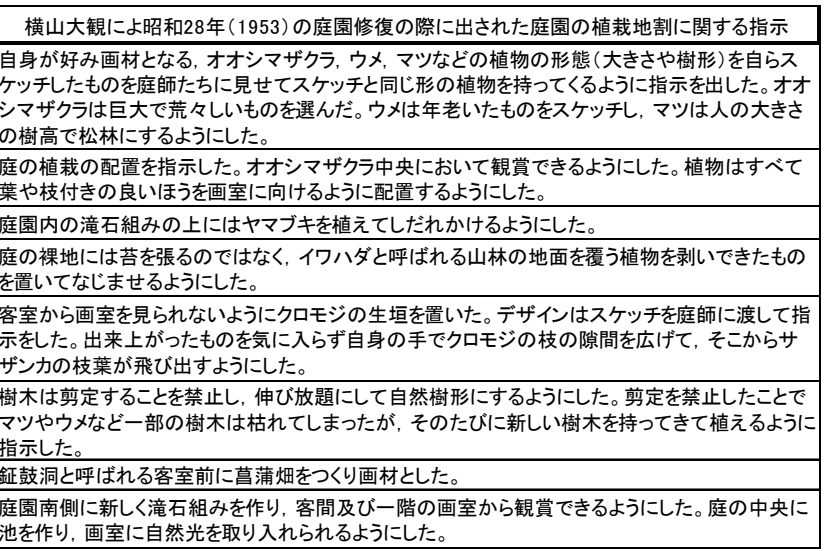

昭和 20 年 (1945) の東京大空襲により邸宅は基礎と土蔵を残し て焼失し，庭園も池の護岸や滝石組みなどの地割, 一部の樹木を 除いて被災した。このとき大観は，世田谷区岡本町の小坂順造宅

(現，旧小坂家住宅）の離孔に避難していた。その後は熱海伊豆 山の別荘へと疎開して 10 年ほど暮らすが，昭和 29 年（1954）に 別荘を引き払い，上野池之端の元の場所に自宅と庭園を再建し移 り住んだ。その 4 年後の昭和 33 年 (1958) 大観は亡くなるが, 最 後に池之端の地に移り住夕住宅・庭園を再建し，修復したことか らもこの場所を愛していたことがうかがえる。

\section{（3）旧横山大観邸庭園の現況と大観の庭園に関する指示の確認}

旧横山大観邸は東側に不忍通りに面した敷地を持ち，庭園部分 は図－1のように，東側に表門から中門までの前庭と，中門から 玄関までの玄関庭, 高さ $4 \mathrm{~m}$ ほどの塀に隔たれ, 表門から見ること ができない南側の主庭，邸宅の東側にある坪庭に分けられる。

これらの庭園の現況をヒアリング調査結果及び作品概要調査結 果 (表一1) の内容を確認しつつ分析した。まず，前庭には表門か ら入るとその正面には塀を背景に大きなさざれ石が据えられてお り, この石は戦前からのものである。そして, すぐに大きく右に 曲がる園路と，玄関と立関庭を隠すように中門があり，園路は丸 い自然石の平らな部分をそろえて, 目地を均一にした延段であり, 岩城造園の得意とする手法で藤井氏が一人で何日もかけて仕上げ たという。植栽は, イロハカエデ, ウメなど大観の好む樹木の他, ヤマモモ, サザンカ, ウバメガシで少し暗くうっそうとしており， 大小様々な景石が配され山居を訪れたような雰囲気を持つ。

次に中門をくぐると居宅玄関と一体化した，前庭とは隔絶され た玄関庭となっている。イロ八モミジ，ウメなど大観の好む落葉 樹木を中心に植栽され, 前庭と比べ明るい印象を受ける。玄関に は土間がなく, 外に据えられた沓脱石で, 直接に式台にあがるよ うになっている。これにより立関と玄関庭との境をなくし一体的 に感じさせている。山居のような前庭を外と考えると, あかるい 空間の玄関庭は，すでに玄関の内と考えることもできる。

坪庭には小ぶりな四角形石灯籠が置かれている。かつて八チク が植えられており，大観は「夜」（1922）という作品で自宅のタケ にとまったミミズクを描いている ${ }^{13)}$ 。しかし，日照条件などの生 育状況の悪さからは八チクは枯れ現在はカリンが植えられている。

最後に，大観が庭園デザインに大きく関与した主庭は，彼の指 示で植えられたオオシマザクラやイロハカエデやウメが図ー1 の 鉦鼓洞 (客室) や大観が庭を眺めた画室からほど近い場所にあり， よく観賞することが出来る。ネズミモチやモッコク，スダジイな どの常緑樹で敷地の境目や壁際を植栽しており隣の建物を隠して いる。かつて存在したと語られた人の背丈ほどの樹高で 100 本ほ ど植えられた赤松林は庭の南東に, 菖蒲田は鉦鼓洞近くの南側に 広がっていたといらが既に無い。大観が存命時に，アカマツの剪 定を禁止したことや，元々日陰地である生育環境の悪さなどによ り枯れ, ショウブは画材として必要がなくなり, 管理更新する人 の不在が消失の理由と考えられる。

そのほかにも画室に光を取り入れるために建物近く, 東から西 一庭の中央につくられた池が特徵的である。またその池に注ぐ, 南側につくられた滝石組夕と流れの水みちは, 画室からの観賞も 視野に入れていたが，現在は滝・流れを循環する水流用ポンプの 老朽化から止水している。ヤマブキは変わらず庭中央付近の石組 みにかかり花を咲かせている。“ヤマハダ”と呼ばれた山林下床の 地被植物をはいだものは根付かなかったのか，今は見られず庭園 はコケに覆われている。また，かつて鉦鼓洞からの画室への視線 を遮る目的で，大観がつくらせたという大きめのクロモジによる 袖垣は既に無い。このように大観指示による庭園デザインのいく つかは失われたが，水流が止まり，建物（画室，客間）に近接し ている池部分が狭められた ${ }^{14)}$ 以外に地割に大きな変化はなく, 大 


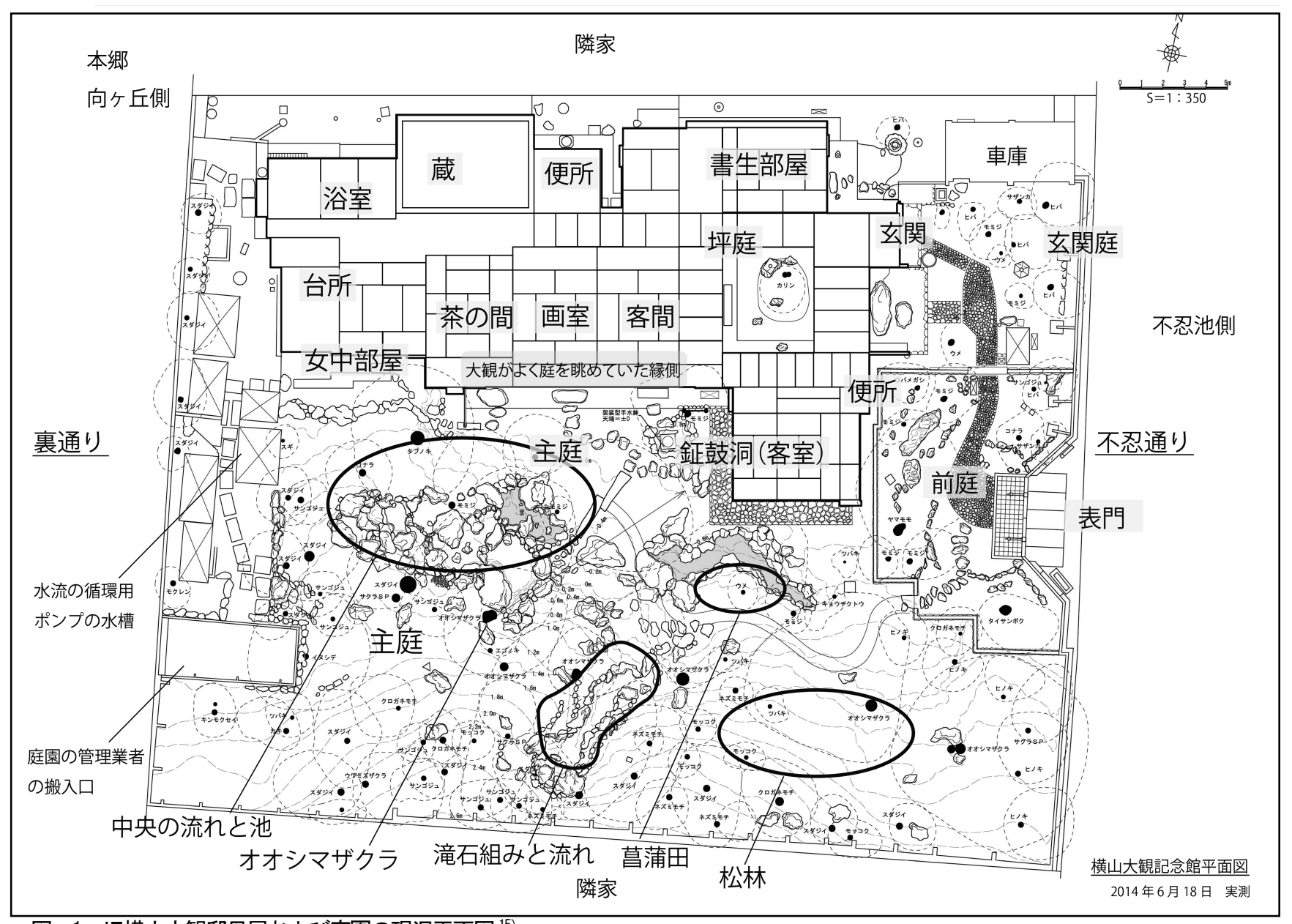

図－1＼cjkstart旧横山大観邸母屋および庭園の現況平面図 ${ }^{15)}$

きく育ったオオシマザクラやウメなどの植栽が大観の絵画世界を 表現しつづけ，自然光を取り入れるための池などの創作活動をサ ポート寸るための庭園デザインはその名残をのこし，近代日本画 家の住宅画室庭園としての特徵を今に感じ取ることができる。

\section{（4）横山大観の描いた植物の特徵}

大観は，花鳥画や風景画では好んでサクラ，マツ，ウメ，を描 いた。一般的な花鳥画や風景画は技巧的あるいは色彩的な美しさ ばかりを表現し，自然から切り取られたものであるのに対し，難 波（1954）は，「大観の植物が，大自然の気を帯びた，精神美の象 徵である。と評している ${ }^{16)}$ 。その理由として，大観の「自然を 観て、それをすぐにものにするということは難しい。頭に一杯し まっておいて、何年か経って、自然の悪い所は皆消えて、いい印 象ばかりが頭に残る。その頭に残ったものを絵にすれば、前に観 た自然とは違うが、画家の個性はハッキリと出る。」 ${ }^{17)}$ という言 葉を残し，大観のスケッチに対しては「写生は自然の真髄を理解 寸る法であり，制作の重要な基礎条件の一つであり，大いに必要 であることは言うまでもないが，日本画における写生は，単なる 写形でなく，写意であって，事物の本然的な生命を感得し，その ものの精神性格を把握し, 物神二面の完全を期すべきである。」 ${ }^{18)}$ というような発言をしていることが挙げられる。スケッチを生涯 多く描き, スケッチに対し並々ならぬ信念を持っていた大観だが, スケッチをそのまま絵にするということはなく，実際に自分の目 で見た自然を一度頭の中にしまい込み，その中から心に残った自 然の美しい姿だけを描いたと考えられる。

池田（2006）は「大観の花鳥画の分析で，植物の形態は園芸品 種はほとんどなく野生種である。と指摘し, 荒々しいヤマザクラ やウメなど自然に自生する力強いものばかりであるという ${ }^{19)}$
また，彼の描いた植物に共通した特徵として花や枝や葉は重なり 合わず，すべて表を向いていることがある20)。「秋色」(1917）や 「夜桜」（1929），「紅葉」（1931）など花鳥画の代表作は夕な葉や 花の表面が描かれており，重なりはほとんど描かれていない。

（5）横山大観の絵画作品と庭園との関係

藤井二郎氏によれば横山大観は, 庭園の修復に当たり様々な指 示を出し, 庭園デザインに大きく関与し, 横山隆氏によれば大観 は画家を志寸前は，建築家を目指しており画家にならなければ建 築家になっていたという。また, 旧横山大観邸は大観自身の設計 から建築されていることからも建築に対する関心がうかがえる。 その絵画作品「千ノ與四郎」(1918) は千利休と茶庭が画題だが, 桂離宮や大徳寺など京都の著名な茶庭に取材し, 俯瞰の構図で茶 庭や庭木の生い茂る様子などを描き, 細かな部分まで精緻に描写

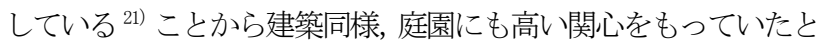
推察される。

表一 1 の藤井二郎氏から得られた大観の庭園づくりに対する指 示した内容で, その絵画作品と大きく関係があると思われるのは, 庭園内に自身が好んだ植物（オオシマザクラやウメなど）につい ては自らスケッチしたものを庭師たちに見せて, スケッチと同じ 形態の植物を持ってくるように指示を出したことや，植物の葉や 枝の表面を画室に向けて配置したことが挙げられる。これは大観 の絵画の中の植物の特徴である葉や枝付きの良い表側をむける構 図と同じである。他にもヤマブキを石組みの上に植えて枝垂れか ける構図は「あまご」(1943), 画室や邸宅から離れて配された松 林は，生涯多く描いた富士山や海の絵画に共通して登場する松林 と同様であり、これらのように庭園の構成と絵画の中の植物の構 罒には類似点が多く見つかるため、大観は自身の絵画世界を庭園 内にも表現しようとしたと考察される。また、画材として観賞利 
用するために植物を剪定，配置したり，画室への採光を意識して 袋状の池を庭の中心に置くなど，庭園の地割や材料は大観の画家 としての制作環境を整えるために大いに影響を受けていた。大観 は日本画の制作で非常に重視したスケッチにおいて，写生するも のが持つ背景や精神性を強く意識した。これは写実主義とは正反 対であり，その感性は庭園にも表れている。それは自然風景を， 一般的な庭園では写実的な手法である仕立てられた植物やコケで 表すのに対し, 植物の剪定を禁止して伸び放題にしたり，“ヤマハ ダ”（山林の地被植物を剥いできたもの）で庭園内を覆うことで， 象徵的あるいは精神的に表現したことが挙げられよう。

\section{5. 大観邸が立地した池之端の意味}

横山大観は戦災で住居を失い，熱海伊豆山の別荘に生活してい たが, 再び池之端に住宅を旧来どおりに再建し, 庭園を修復した。 土地に固有な庭園の意味を考えたとき，池之端という場所への大 観のこだわりの意味の考究は, この庭園の特徵を再考するに重要 と考え，この場の歴史，景観，横山大観との関係に関して考察し た。

\section{（1）大観が好み活動の中心とした池之端}

東京都台東区池之端は明治時代，下谷区茅町と呼ばれていた。 不忍池の西側に位置し茅の茂る地という意味の町名で，本郷向ヶ 岡の丘阜を背にし，東に面して不忍池と弁天堂を望み，上野の東 㕡山全景とを見渡寸景勝の地であった。不忍池周辺は明治から昭 和にかけて多くの文士や芸術家が住居を構えた文化的に優れた土 地であった ${ }^{22)}$ 。また日本美術院や，東京美術学校（現東京藝大） にも近く, 学生時代, 東京美術学校助教授時代と不忍池周辺を活 動の中心にしてきた大観にとっては非常になじみの深い場所でも あった。大観は大正 11 年 (1922) 東京，琅玕堂にて開か冰た「東 京名所古跡横幀展」という画家たちが自身の好きな東京の名所を 選んで描き出品する展覧会に，不忍池を描いた作品を出展してい る。大観がいかに不忍池を好み，池之端の地を気に入っていたか ががわかる。

大観は邸宅を戦災で失い熱海伊豆山の別荘に落ち着くが，以前 と変わらず，むしろ積極的に制作活動に取り組んだ。大観は戦時 中，金銭面で軍部への援助を厭わなかったが，戦後は復興への援 助を惜しまずに行った ${ }^{23)}$ 。昭和 21 年（1946）には再興美術院展 も主導で行うなど, 芸術文化の復興でも大いに活躍したのである。 忙しく東京と熱海を行き来することになり，足を悪くした晚年の 大観にとっては辛く，住文慣れた池之端を終の棲家として選んだ のには，腰を据えて制作活動に打ち込むための，快適な制作環境 づくりといった理由もあると考えられる。

\section{（2）水戸藩士の家系をもつ大観にとっての池之端}

横山大観は茨城県に生まれ，祖父・父共に水戸藩士であった。 勤王派であった父・捨彦，思想家としても著名であり国粋主義者 とも称された師・岡倉天心の影響を色濃く受けた大観は，自身も 国粋主義的な面を持ち，「正気放光」(1944) と題された富士の他， 生涯にたくさんの日本の象徵である富士山にちなんだ作品を描い ている。この「正気放光」は幕末の水戸学の代表者・藤田東湖の 「正気の歌」に，日本人の正気が集まり富士山となり，時代によ り衰退しようともそのたびに光を放つと詠われたことに題をとっ ている ${ }^{24)}$ このことからも，大観は幼いころより水戸学の気質の

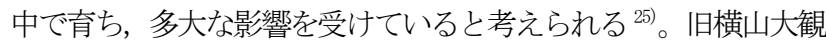
邸がある池之端の北西には，水戸藩の屋敷である駒込邸が位置し た。原（2010）は，水戸藩駒込邸庭園は，水戸偕楽園が千波湖を 中国の神聖な湖である西湖にたとえ，千波湖を含む景観を縮景し ているのと同様に，不忍池を小西湖 (小さな西湖) として縮景し ているとした ${ }^{26)}$ 。駒込邸の水戸藩士にとって，不忍池は思想的に も空間的にも非常に重要な場所であったことがうかがえる。また,
江戸時代幕末には水戸藩の藩政に大きく影響を与えた梁川星婩や 小野湖山らも池之端で学んでいることから ${ }^{27)}$, この地が大観にと って風致美観的な意味以上に, 思想信条的にも意味をもつ場所で あったと推察される。

\section{6. まとめ}

旧横山大観邸庭園は大観自身が庭園内の主要な植物の種類や配 置を決め, サクラやウメ, アカマツは自らスケッチしたものを庭 師に見せて注文をだした。また，庭園奥の滝石組みや流れ，建物 に沿った中央の池などの地割が大観の指示によってつくられ，石 組みの上にヤマブキを植えるなど絵画の構図と同様に庭園の構成 がなされている場所があり, 自身の絵画世界を積極的に表現しよ うとしていると考えられる。庭園内の植物は画材として利用する もの，中央の池や流れはアトリエへ自然光を取り入れるためのも のであり，大観の創作環境を整える役割を持ち、庭園の地割や植 栽に近代日本画家横山大観の影響を大きく受けたものであった。

大観は絵画制作で大切にしたスケッチで，対象の精神性を強く 重視する感性を庭園づくりに取り入れ, 剪定を禁止し自然樹形に なるようにした植物や “ヤマハダ”により庭園の自然風景を象徴 的に表現することなどに, 同時代に活躍した日本画家たちの庭園 に共通する，写実的に実物大に自然風景を表現する自然主義風景 式庭園との違いが見られた。また，園外景観を庭園内に借景して いないことも違いとして挙げられる。不忍池は幕末から昭和にか けて多くの文士や芸術家が移り住んだ文化的にすぐれた場所で, 横山大観のルーツである水戸藩との関係が深く, 彼にとって信条 的, 思想的に非常に重要な場所でありながらも, 不忍池の景色を 庭園内に借景して，直接眺めることはしなかった。これは，横山 大観が絵画制作と同様に不忍池の持つ精神性や象徴性を重視して いたのではないかと考えられるが, その考察は今後の課題である。

謝辞 : 横山大観記念館館長である横山隆氏，庭園の修復に携わ った藤井二郎氏には多大なご支援いただき感謝を申しあげます。

\section{補注及び引用文献}

1）小野健吉 (2000) : 京都を中心とした近代日本庭園の研究:奈良国立文化財研究所, 81-120

2）前掲書 1） $81-120$

3）吉田博宣 (2009) : 画家川合玉堂の庭園観と旧別邸二松庵庭園 : 日本造園学会誌ラ ンドスケープ研究 72(5), 447-450

4）難波専太郎（1954）: 横山大観 : 美術探究社，58

5）高橋満（1989）: 地籍台帳・地籍地図（東京）第 7 巻 : 地図資料編纂会, 213

6) 船橋治 (2011) : 東京地籍図 第6回配本 台東区編: 不二出版, 403

7）興津要（1997）: 明治新聞事始め「文明開化」のジャーナリズム : 大修館書店, 37

8) 齋藤 康彦 (2008) : 近代数寄者の大寄世茶会と社会文化事業 : 山梨大学教育人間 科学部紀要 10,301

9）横山大観（1999）: 横山大観「大観画談」：日本図書センター, 169

10）横山隆氏談（2013年 7 月 23 日にヒアリング以下同様）

11）前掲書4） 154

12）横山隆氏談

13）横山隆氏談

14）横山隆氏談

15）庭園図は自身の測量によるもの、建築図は 1976 年に (株) 建文によって作成され 横山大観記念館より提供されたものを使用

16）前掲書 4), 45

17）富山県水墨美術館 (2001)：足立美術館所蔵横山大観展 : 足立美術館学芸部，131

18）前掲書 4$), 19$

19）湯原公浩 (2006) : 気隗の人 横山大観 : 平凡社, 94

20) 前掲書 4), 141-142

21）浅田彦一 (1918) : 時局の印象: 太陽 第 24 巻 第 12 号, $28-32$

22）永井荷風 (2012)：上野: 青空文庫，4

23）前掲書 4), 130-131

24）吉沢忠: 日本近代絵画全集 15 横山大観 : 講談社, 53

25）芳賀登（1996）: 近代水戶学研究史 : 冬至書房，418

26）原祐一 (2010) : 水戸藩駒込邸の研究--藩邸内外の景観と造園の検討 : 東京大学史 紀要 $(28), 46$

27) 前掲書 4), 94 